\title{
SCALING UP DELIBERATIVE DEMOCRACY AS DISPUTE RESOLUTION IN HEALTHCARE REFORM: A WORK IN PROGRESS
}

\author{
CARRIE MENKEL-MEADOW*
}

INTRODUCTION

When healthcare reform was being debated in the United States last year, many groups-including members of Congress, White House representatives, and other public and private policy groups-attempted to hold and facilitate "town hall" meetings to demonstrate how ADR-like processes, such as deliberative democracy and consensus building, could be used to encourage deliberative consideration of healthcare proposals. Instead of model deliberative sessions, however, most of these sessions turned adversarial (and were then subverted for more "interrupted" democracy), as they were "sabotaged" by opponents of national healthcare reform. This paper reflects on the deliberative democracy and consensus building literature that suggests how less-adversarial processes might be used to achieve good policy making and contrasts the theory with what actually happened in practice last year. How does our theory and practice of deliberative democracy have to change to

Copyright ( 2011 by Carrie Menkel-Meadow.

This article is also available at http://www.law.duke.edu/journals/lcp.

* Chancellor's Professor of Law, University of California Irvine Law School and A.B. Chettle, Jr. Professor of Law, Georgetown University Law Center. With thanks to the other participants and commentators at the See You Out of Court? The Role of ADR in Healthcare symposium on October 8, 2010, at Duke University School of Law, especially Orna Rabinovich-Einy, Ethan Katsh, Miki Alberstein, Moti Mironi, and Nancy Dubler, for helpful comments and reactions to this paper; Jean Su for superb research assistance; Dr. Robert Meadow (political scientist and consultant) for political counsel and always-trenchant critique; Lawrence Susskind for comments and reactions from experience with the processes discussed herein; and to the Law and Contemporary Problems editors and staff for their excellent management and organization of both a very stimulating event and production of this important publication. This article was written just before the November 2, 2010, elections. If anything, things have gotten much worse on the deliberative democracy front since then. Newly elected Republican majorities in both federal (House of Representatives) and state legislatures have attempted to repeal or refuse financial authorization for or implementation of the Patient Protection and Affordable Care Act. This is unlikely to occur, given the composition of the U.S. Senate, President Obama's ability to veto any proposed changes that would not have enough votes to override such a veto, and-perhaps surprisingly to some-continued majority support (including that of many Republican voters) for many of the healthcare reforms. See Kaiser Health Tracking Poll, KAISER FAMILY FOUND. (Nov. 9, 2010), http://www.kff.org/kaiserpolls/8120.cfm ("Several key provisions of health reform remain popular, even among those who support repeal of all or parts of the law."). 
actually be effective? Was what happened peculiar to healthcare policy making, or are there lessons to learn generally for deliberative democracy theory and practice?

When President Barack Obama was elected in 2008, hopes were high for substantive reform in several important domestic arenas-most prominently, healthcare, labor law, immigration, and education, along with efforts to deal with the economic recession. ${ }^{1}$ Shortly after his election, several bloggers and fellow dispute resolution activists suggested that "we" should advise the President to make use of our "new" field of consensus building, facilitated deliberative democracy, public fora for policy making, and various dialogue techniques to engage the public in participating in these reforms. ${ }^{2}$

Deliberative democracy is both a political theory ${ }^{3}$ and a practice that has built upon insights from the conflict resolution movement of the 1980s. ${ }^{4}$ The modern ADR ("Alternative" or, more commonly now, "Appropriate" Dispute Resolution) movement was born of dissatisfaction with the high-cost, inefficient dispute processing and unnecessarily brittle or binary solutions of the conventional legal system and courts. At about the same time, deliberative democracy ideas were birthed out of dissatisfaction with similarly polarized and inefficient decision making in our political system. Yet, as these two social movements (ADR and deliberative democracy) have attempted to deal with similar issues and processes, they have offered slightly different rationales and practices, with important consequences for what recently occurred in the "failed" town-hall meetings about healthcare reform.

1. Of course, hopes were also high for more deliberation (and changes in policy) on the conduct of the two wars in Iraq and Afghanistan.

2. I advised against this on the dispute resolution listserv because I thought it was unnecessary and paternalistic of us to suggest such things to a master community organizer and student of mediation while at Harvard Law School. I knew that the new President-elect was quite aware of consensusbuilding and mediative techniques. The White House soon began a public comment and a public deliberation space on its website, whitehouse.gov: the OfFICE OF PUBliC ENGAGEMENT BLOG, http://www.whitehouse.gov/administration/eop/ope/blog (last visited Jan. 15, 2011), and the OPEN GOVERNMENT INITIATIVE BLOG, http://www.whitehouse.gov/open/blog (last visited Jan. 15, 2011). There is now also healthcare.gov to provide information (and elicit questions, comments, and stories) on the Patient Protection and Affordable Care Act of 2010, Pub. L. No. 111-148, 124 Stat. 119.

3. For analysis of deliberative democracy as a political theory, see generally JAMES BOHMAN, Public Deliberation: Pluralism, COMPlexity, AND Democracy (1996); Debating Deliberative Democracy (James S. Fishkin \& Peter Laslett eds., 2003); Deliberative DEMOCRACY HANDBOOK: STRATEGIES FOR EFFECTIVE CIVIC ENGAGEMENT IN THE TWENTY-FIRST CENTURY (John Gastil \& Peter Levine eds., 2005); Deliberative POlitics: Essays ON DEMOCRACY AND DisAgreEMENT (Stephen Macedo ed., 1999); JOHN S. DRYZEK, DELIBERATIVE DEMOCRACY AND BEYOND: LibERALS, CRITICS, CONTESTATIONS (2000); ARCHON FUNG \& ERIK OLIN WRIGHT, DEEPENING DEMOCRACY: INSTITUTIONAL INNOVATIONS IN EMPOWERED PARTICIPATORY GOVERNANCE (2003); AMY GUTMANN \& DENNIS THOMPSON, DEMOCRACY AND DISAGREEMENT (1996).

4. Carrie Menkel-Meadow, Deliberative Democracy and Conflict Resolution: Two Theories and Practices of Participation in the Polity, DisP. ReSOL. MAG., Winter 2006, at 18; Symposium, Raising the Bar: What Deliberative Democracy Means for Dispute Resolution, DISP. RESOL. MAG., Winter 2006, at 1, 5-27 (first section of issue titled Focus: Deliberative Democracy, presenting several illuminating articles on the subject). 
In this article, I explore the rationales and practices of deliberative democracy and conflict resolution as they were enacted in the so-called townhall meetings 5 about healthcare in the United States in 2009 and offer my analysis of what went wrong and why. The failure to adapt old conceptions of town-hall meetings to modern political realities in the healthcare-reform battles cautions us to reconceptualize both theory and practice as we try to "scale up" conflict resolution methods for larger, highly conflictual disputes at the societal, not individual, level. At its core, my argument is that naïve political and philosophical theories about the use of "reason" in democratic deliberation fail to take adequate account of two other major modes of modern discourse: bargaining and affective (involving emotion and ethical, religious, or strongly held values) or feeling-based arguments. If dispute resolution techniques based on ADR principles of focusing on parties' needs, interests, and underlying values are to be used for major policy decisions aiming to increase polity participation in decisions affecting the lives of all, then those techniques (and the theories on which they are based) may require some adaptation to largescale moments of deliberation and decision making. At the conclusion of this article, I offer some suggestions for both reconceiving and restructuring such processes for different kinds of uses for different kinds of issues.

II

\section{THEORIES OF DELIBERATIVE DEMOCRACY}

Modern deliberative democracy theories derive mostly from the work of social and political philosopher Jürgen Habermas, particularly from his work on "ideal speech conditions" for fair deliberation on political decisions affecting those governed by the decisions made. ${ }^{6}$ Like many similar theorists who "privilege" reason, Habermas argues that under certain conditions of equality, fairness, and "uncoerced" speech, decisions should be made on the basis of persuasion with all interested parties able to argue for their "positions." No decision should be adopted unless all those affected by a decision have an opportunity to persuade each other. Habermas, like others who have theorized about public-participation models of communication, ${ }^{8}$ is, in fact, quite optimistic about the ability of rational suasion to persuade even those with differing values to come to an agreement. Notions of rational persuasion assume openness to

5. The most basic critique of these so-called town-hall meetings is that they were not "town halls" at all because they were often addressed to much larger groups (whole congressional constituencies, rather than towns or smaller communities) and because they were not really deliberative or decisionmaking events - they were convened to persuade people to support particular policy choices, more or less already made.

6. 1 JÜRgEN HABERMAS, THE THEORY OF COMMUNICATIVE ACTION: REASON AND THE RATIONALIZATION OF SOCIETY 177 (Thomas McCarthy trans., 1984).

7. Id. at 179 .

8. E.g., BOHMAN, supra note 3, at 23-25; DRYZEK, supra note 3, at 47-55. See generally DELIBERATIVE DEMOCRACY (John Elster ed., 1998) (presenting various contributions supporting decision by discussion or deliberation as an alternative to voting in political decision making). 
hearing other points of view. This assumption did not seem to hold true empirically at the healthcare events, however, for "both" sides appeared to attend with the intent either to persuade people to support the Administration's healthcare proposals or to defeat those proposals-with both sides delivering various forms of "one-way lectures," rather than participatory and attentive conversations. At the outset, these events were not structured as true policydeliberation or decision-making events. Rather, they were designed to persuade-or, at the very best, to educate about what the Administration had already proposed-or to disrupt both the events themselves and the policyadoption (legislative) process.

Many theorists who recognize the complexity and difficulty of highly charged issues-like abortion, gun control, immigration policy, animal rights, discrimination, AIDS and HIV treatment, gay marriage, and war policy-are still hopeful that under proper conditions, those with very different views can come together and, under the right conditions, ${ }^{9}$ can deliberate with each other, becoming better informed (and, even occasionally, changing their views) $;{ }^{10}$ reach decisions by voting, consensus building, ${ }^{11}$ or preference trading (negotiation); or, at the very least, come to understand each other better ${ }^{12}$ with "recognition" and perhaps also enhanced feelings of "self-empowerment."13

Deliberative democracy is intended to have many goals: identifying issues for policy development; sifting, choosing, and modifying policy; and sometimes actually facilitating decision making on behalf of various levels of political and legal action. Who defines the goals of any particular deliberative democracy "event" is an important theoretical and practical issue. The goals of the healthcare town halls were somewhat simplistically or amorphously defineddid government representatives seek to persuade members of the public to support whatever plans were in the offing at the time (May through September 2009), or were officials really open to hearing about new ideas and amendments to various proposed bills? On the opposition side, objectives ranged from defeat of any administration proposed plan to more specific opposition. In one sense, the town halls were not a "failure" from the perspective of the oppositionists-

9. E.g., BRUCE ACKeRMAN \& JAMES S. FishKin, Deliberation DAY 4-5 (2004); GUTMANN \& THOMPSON, supra note 3, at 7-8, 55, 95. At the Duke Law See You Out of Court? The Role of ADR in Healthcare symposium, Nancy Dubler expressed doubt that matters of "life and death" could ever be deliberated rationally, especially in very large groups. Nancy Neveloff Dubler, Professor Emerita, Albert Einstein Coll. of Med., Yeshiva Univ., Commentary at the Duke Law and Contemporary Problems Symposium: See You Out of Court? The Role of ADR in Healthcare (Oct. 8, 2010).

10. James S. Fishkin, When the People Speak: Deliberative Democracy and PubliC CONSULTATION 161-69 (2009).

11. See generally, e.g., SUSAN L. CARPENTER \& W.J.D. KenNEDy, MANAGING PUBLIC DisPuTES: A PracticAl Guide fOr Government, Business, AND Citizens' Groups (2d ed. 2001); The CONSENSUS BUILDING HANDBOOK (Lawrence Susskind et al. eds., 1999).

12. For examples of dialogue models to assist in facilitating this result, see PUBLIC CONVERSATIONS PROJECT, http://www.publicconversations.org (last visited Jan. 15, 2011).

13. Robert A. Baruch Bush \& Joseph Folger, The Promise of Mediation: The TRANSFORMATIVE APPROACH TO CONFLICT 55-56 (rev. ed. 2005). 
the public option was removed from the bill that finally became law. Actually, the wide media coverage of the events probably gave the oppositionists further voice by covering the more dramatic moments of contest and confrontation, raising important questions about media coverage and transparency or confidentiality in deliberative events.

Several other important, recent theorists express more realistic (some would say pessimistic) notions about our ability to rationally deliberate and reach decisions about "the good." In his Tanner Lectures, social philosopher Stuart Hampshire suggested that, after a full life of theorizing about the substantive "good," he had come to realize that in our modern, diverse societies (including value, as well as demographic, diversities), we were unlikely to come to any true agreement on "the good." ${ }^{14}$ Therefore, at the end of a long and productive career in moral philosophy, he concluded that we were more likely to come to some agreements-not on "the good," but on procedures for arguing about what policy outcomes we could actually accomplish. In his book, Justice Is Conflict, Hampshire suggested that the Anglo-American mode of adversary argument audi alterum partem, or "hear the other side," could eventually be made an almost universal procedure of fairness and good decision making if we could really give adequate voice and truly listen to the other side. ${ }^{15}$

In a variety of venues, I have both praised and criticized this basic idea of the universal value of proceduralism and fairness by suggesting that more modern theories of deliberative democracy and conflict resolution, which involve multiple issues and many "parties," should be modified to say, "Hear [and understand] all the other sides."16 This might also entail some "process pluralism" (or a greater diversity of procedures, not just adversary argument). Concern for fair process or "procedural justice" ${ }^{17}$ might be universal, but what process is considered fair might indeed vary in different circumstances. Hampshire did not fully explore these scenarios, but they certainly remain a concern for all dispute resolution scholars ${ }^{18}$ and the new practical field of dispute-system design. ${ }^{19}$

14. StuARt Hampshire, Justice Is CONFlict 33-34 (2000). This work is based on arguments Hampshire first delivered in Justice Is Conflict: The Soul and the City, The Tanner Lectures on Human Values, Delivered at Harvard University (Oct. 30-31, 1996) (transcript available at http:// www.tannerlectures.utah.edu/lectures/documents/Hampshire98.pdf).

15. Id. at $8-9(2000)$.

16. E.g., Carrie Menkel-Meadow, Peace and Justice: Notes on the Evolution and Purposes of Legal Processes, 94 GEO. L.J. 553, 557 (2006).

17. See generally E. Allan Lind \& Tom R. TYler, The Social Psychology of Procedural JUSTICE (1988) (providing theory and research on procedural justice and exploring its social implications).

18. E.g., Carrie MenKel-Meadow et Al., Dispute Resolution: Beyond the AdVERSARIAl Model 581-633 (2d ed. 2011). See also THE HANDBOOK OF CONFLICT RESOlution (Morton Deutsch \& Peter T. Coleman eds., 2000); THE HANDBOOK OF DisPUTE RESOLUTION (Michael L. Moffitt \& Robert C. Bordone eds., 2005).

19. E.g., Symposium, Dispute Systems Design, 14 HaRV. NegOt. L. ReV. 1 (2009). 
Modern conflicts and disputes actually often involve multiple parties and multiple "sides" to be heard (despite their characterization as either Republican or Democratic, conservative or liberal, and red or blue ${ }^{20}$ ). Polarization of most political issues, but especially healthcare, makes gradations and variations of views and policy outcomes impossible to recognize and discuss because voting and other political procedures ultimately require binary decisions: yes or no. Although courts must usually come to win or lose binary solutions, true deliberation before the fact of legislation or regulation could actually permit more nuanced policy outcomes; yet, in fact, modern American political behaviors have tended to make the legislative and regulatory processes more oppositional and adversarial. ${ }^{21}$ One essential question was whether there were "multiple" issues to be traded or bargained for or only a "single" issue of support for healthcare (as the Administration proposed). Similarly, to the extent that healthcare became a single (and "signaling") issue of support for the larger political regime, it was not "nested" in the many other issues that could have been deliberated and perhaps traded. The healthcare town halls failed to explore basic principles of complex voting issues (such as simple-majority, super-majority, and Condorcet-preference voting ${ }^{22}$ and multiple-issue trading, a staple of consensus-building procedures. These failures made it virtually impossible for the town-hall meetings to affect policy outcomes (which is not what they seemed to be designed to do).

Like Hampshire, economist-turned-social philosopher Amartya Sen has also recently suggested we need a turn to more realistic political philosophy and policy-choice practices. ${ }^{23}$ Because the "perfect can be the enemy of the good," ${ }^{24}$ quests for universal theories of political justice, such as John Rawls' classic efforts for a "veil of ignorance," 25 prevent us from more realizable "second best"

20. E.g., Richard H. Pildes, Why the Center Does Not Hold: The Causes of Hyperpolarized Democracy in America, 99 CALIF. L. REV. (forthcoming 2011) (N.Y.U. Sch. of Law, Public Law Research Paper No. 10-47, 2010), available at http://ssrn.com/abstract=1646989; Sam Tanenhaus, The Myth of Consensus Politics, N.Y. TIMES, Oct. 21, 2010, available at http://www.nytimes.com/ 2010/10/24/books/review/Tanenhaus-t.html.

21. E.g., Robert A. Kagan, Adversarial Legalism: The American Way of Law 188 (2001) ("The United States . . strives to subject the political struggle over regulatory policy to the constraints of legal rationality, which gives both regulated business and proregulation advocacy groups yet another set of weapons to foil regulatory decisions that they may dislike.").

22. See Menkel-Meadow ET AL., supra note 18, at 585-86; AmARTYA Sen, The IdeA of JUSTICE 92 (2009) (describing French social-choice theorist Condorcet's demonstration that majority rule can be thoroughly inconsistent - the "Condorcet Paradox"); LEIGH L. THOMSON, THE MIND AND HEART OF THE NEGOTIATOR 222-24 (4th ed. 2009) (discussing voting issues and paradoxes).

23. SEN, supra note 22, at 194-207, 225. See generally Cesar Arjona, Arif Jamal, Carrie MenkelMeadow, Victor Ramraj \& Francisco Satiro, Senses of Sen, 7 INT'L J.L. IN CONTEXT (forthcoming 2011).

24. The original quote in French is "Le mieux est l'ennemi du bien." VOLTAIRE, 2 DictionNAIRE PHILOSOPHIQUE 49 (Lebigre Freres ed., 1834) (originally appearing in Voltaire's poem, La Bégueule (1772)). The literal translation is "The best is the enemy of good," THE OXFORD DICTIONARY OF QUOTATIONS 797 (Elizabeth Knowles ed., 5th ed. 1999) (quotation number 11), but the more common translation is "The perfect is the enemy of the good."

25. JOHN RAWLS, A THEORY OF JUSTICE 118-23 (1999). 
injustice reduction efforts when we debate universal and unrealizable "justice." Sen suggests we look at more varieties of experiments on the ground-with empirical data and evaluation-searching for attempts to reduce poverty, disease, war, and the aftermaths of natural (as well as man-made) disasters. ${ }^{26}$ One size will not fit all, these philosophers caution, in substance or in procedure. Rather than seeking impossible "transcendental" solutions to a myriad of human problems and suffering, Sen suggests we should seek "comparative broadening" by looking more at how other systems deal with similar problems (such as socialized medicine- "horrors" to many Americans, but not to a large part of the rest of the world-and different models of agriculture and food distribution) ${ }^{27}$ And, he suggests, there could be a "plurality of sustainable reasons" (instead of a single train of rational thought) for making policy choices. ${ }^{28}$ In his recent book, Sen traces more (nonwestern) sources of models for political decision making, in both process and possible choices of action, especially in situations of extreme human devastation-for example, poverty, floods and other natural disasters, and starvation (which he sees as maldistribution and mismanagement of resource problems). ${ }^{29}$ These situations require much experimentation (rather than uniform or unitary solutions), as well as different models of management, and then empirical evaluation, along with public (and expert) deliberation.

These more modern "social realist" philosophers continue that other Adam Smithian tradition-not that of the economistic "hand of the free market" Wealth of Nations,${ }^{30}$ but rather the Theory of Moral Sentiments, ${ }^{31}$ in which Smith explores both our altruistic and fellow feeling proclivities. He also identifies a need for an "impartial spectator" to measure what we think and do against the evaluative criteria of some outsider who can encourage "critical scrutiny and public discussion" and expose when we are making assumptions about our own insular needs and wants. ${ }^{32}$ In this, Smith and Sen may be on to something very important about modern deliberative democracy - a theoretical justification for the practical "third-party neutral" or skilled deliberative democracy facilitator, mediator, or moderator.

Notable political philosopher Jon Elster has looked at constitutional processes and outcomes and, in a now-classic study of comparative constitutionalism, has also described his own version of the perfect as the

26. SEN, supra note 22 , at $16-17$.

27. Id. at 400-07.

28. Id. at 225-35.

29. Id. at 323.

30. Adam Smith, An InQuiry into the NATURE AND CAUSES OF the WeAlth OF NATIONS (Edwin Cannan ed., 6th ed. 1904).

31. Adam Smith, The Theory of Moral Sentiments (D.D. Raphael \& A.L. Macfie eds., 1976).

32. Id. at 32 . 
enemy of the good. ${ }^{33}$ Elster argues that France's constitutional formation processes, which were based on first principles of transparency, publicity, and plenary participation, resulted in a highly fractious and politicized process. ${ }^{34}$ This led to many regime changes (not to mention killings of revolutionary leaders, all in the name of the great abstract and universal values of fraternité, equalité, and liberté) and constitutional instability. In contrast, the American constitutional-formation process in the same era was characterized by secrecy, committee (not plenary) work, and infamously compromised (not principled) solutions to divisive issues-for example, the continuation of slavery and a nondemocratic Senate, as well as the problematic, indirect election of presidents and appointment of senators).$^{35}$ Nevertheless, even with a brutal civil war and over twenty-five amendments, the U.S. Constitution has had a longer and more robust life than France's more "principled" constitution. From this, Elster concludes that process matters and that processes are complicated to structure and manage, depending on the outcomes sought (goals) and those actually achieved (outputs or consequences). ${ }^{36}$

From this and other work Elster has done on the affective dimension of the role of emotion in democratic processes, ${ }^{37}$ it is apparent that true deliberation needs to take account of the process pluralism produced by conflict resolution theory's focus on underlying needs and interests, and at least three separate modes of human discourse: the principled-rational, the bargaining or preferencetrading (negotiation), and the affective and value-feeling, recognizing the importance of the emotional dimensions of discourse. For ease of discussion, Table 1 demonstrates how these different modes of human discourse, coupled with different forms of decision making required in different contexts, produce a broader and wider dimension of possible processes to be used in public-policy deliberation than what occurred in the healthcare debates. ${ }^{38}$

33. Jon Elster, Strategic Uses of Argument, in BARRIERS TO CONFLICT RESOLUTION 236, 244-52 (Kenneth J. Arrow et al. eds., 1995).

34. Id. at $242,244$.

35. See generally Dana Lanksy, Proceeding to a Constitution: A Multi-Party Negotiation Analysis of the Constitutional Convention of 1787, 5 HARV. NEGOT. L. REV. 279 (2000) (presenting the Framers' successful negotiations as an illustration of how deliberative process can be used creatively to solve complex, multi-party issues); Jack N. Rakove, The Great Compromise: Ideas, Interests, and the Politics of Constitution Making, 44 WM. \& MARY Q. 424 (1987) (describing the Federal Convention's process of deliberation over whether to give states an equal vote in the Senate).

36. Elster, supra note 33, at 257.

37. E.g., Jon Elster, Alchemies of THE Mind: RATIONALITY AND THE EMOTIONS (1999).

38. See Carrie Menkel-Meadow, Introduction: From Legal Disputes to Conflict Resolution and Human Problem Solving, in DisPUTE PROCESSING AND CONFLict RESOlUtion xi, at xxxi (2003) (presenting similar version of this table). 
Table 1: Modes of Conflict Resolution

\begin{tabular}{|c|c|c|c|}
\hline $\begin{array}{c}\text { MODE OF } \\
\text { DISCOURSE }\end{array}$ & PRINCIPLES & BARGAINING & PASSIONS \\
\hline \multicolumn{4}{|l|}{$\begin{array}{l}\text { FORM OF } \\
\text { PROCESS: }\end{array}$} \\
\hline Closed & $\begin{array}{l}\text { Some court } \\
\text { proceedings; } \\
\text { arbitration }\end{array}$ & $\begin{array}{l}\text { Negotiation-U.S. } \\
\text { Constitution; } \\
\text { diplomacy }\end{array}$ & $\begin{array}{c}\text { Mediation (for example, } \\
\text { divorce) }\end{array}$ \\
\hline Open & $\begin{array}{l}\text { French Constitution; } \\
\text { courts; arbitration }\end{array}$ & $\begin{array}{l}\text { Public negotiations; } \\
\text { some labor }\end{array}$ & Dialogue movement \\
\hline Plenary & French Constitution & $\begin{array}{l}\text { Reg-Neg (Negotiated } \\
\text { Rulemaking) }\end{array}$ & Town-hall meetings \\
\hline Committees & $\begin{array}{l}\text { Faculty committees; } \\
\text { task groups }\end{array}$ & $\begin{array}{l}\text { U.S. Constitution; U.S. } \\
\text { Congress }\end{array}$ & Caucuses; interest groups \\
\hline $\begin{array}{c}\text { Expert- } \\
\text { Facilitator }\end{array}$ & Consensus building & Mini-trial & Public conversations \\
\hline Naturalistic & & & $\begin{array}{l}\text { Grassroots organizing; } \\
\text { WTO protests }\end{array}$ \\
\hline Permanent & $\begin{array}{l}\text { Government; } \\
\text { institutions }\end{array}$ & $\begin{array}{c}\text { Business organizations; } \\
\text { unions }\end{array}$ & $\begin{array}{l}\text { Religious organizations; } \\
\text { Alcoholics Anonymous; } \\
\text { Weight Watchers }\end{array}$ \\
\hline Constitutive & $\begin{array}{l}\text { UN; national } \\
\text { constitutions }\end{array}$ & $\begin{array}{l}\text { National constitutions; } \\
\text { professional } \\
\text { associations }\end{array}$ & $\begin{array}{l}\text { Civil justice movements; } \\
\text { peace }\end{array}$ \\
\hline $\begin{array}{l}\text { Temporary or } \\
\text { Ad hoc }\end{array}$ & $\begin{array}{l}\text { Issue organizations; } \\
\text { social justice }\end{array}$ & Interest groups & $\begin{array}{l}\text { Yippies; New Age; } \\
\text { vigilantes }\end{array}$ \\
\hline
\end{tabular}

Principles $=$ reasons, appeals to universalism, law

Bargaining = interests, preferences, trading, compromises

Passions $=$ needs, emotions, religion

Closed $=$ confidential, secret process or outcomes (settlements)

Open $=$ public or transparent meetings or proceedings

Plenary $=$ full group participation, joint meetings

Committees $=$ task groups, caucuses, parts of the whole

Expert-facilitator $=$ led by expertise (process or substantive or both)

Naturalistic $=$ leaderless, grassroots, ad hoc

Permanent $=$ organizational, institutional

Constitutive $=$ constitutional

Temporary $=$ ad hoc groups or disputants

Some predicted effects of process on outcome: 
1. Closed (confidential) proceedings are open to vulnerability, inviting more honest and candid expression of interests, needs, and passions; more "trades"; and less posturing.

2. Open (transparent) proceedings require more principled or reasoned justifications, producing more rigidity.

This table places town-hall meetings in the third column. Organized in plenary form, these meetings appeal to basic emotional needs and "passions," rather than to what many hoped would actually happen in the healthcarereform town halls: democratically organized, rational discussion and debate.

So what went wrong when these town-hall meetings, expected to be exemplars of modern deliberative democracy, were disrupted and, as many argued, actually subverted the democratic process? What can the actual practice of the healthcare-reform town halls teach us about both the theory and practice of deliberative democracy?

III

\section{What Happened? Deliberative Democracy and HealthCaRe REFORM TOWN HALLS}

When debate about President Obama's healthcare proposals increased, following the introduction of various congressional bills in 2009 and the failure to develop much bipartisan support (not through any lack of effort by the President and, at least, some Democrats), various politicians-including the President himself and members of the Senate and the House-held community town-hall meetings in the summer and fall of 2009. Many private and public organizations also sponsored a variety of community-based meetings to discuss a very complex set of proposals to reform healthcare, including such issues as coverage of preexisting conditions, coverage of children past twenty-one, public versus private payment plans, ${ }^{39}$ portability, closing the "donut hole" left by the Bush-era drug plan, lifetime caps on insurance coverage, and mandatory participation.

The decisions to hold these meetings could themselves be the subject of a separate paper on healthcare reform and dispute processes, implicating issues of venue choice, articulation of goals, coalition formation, and ordering of negotiation partners. ${ }^{40}$ Perhaps due to the "capture" of the Clinton-era reform process by insurance and pharmaceutical interests and oppositionists in Congress, the Obama Administration and Democratic strategists, flush from a dramatic Presidential victory and a strong majority in Congress in November of

39. Single-payer plans, of course, were off the table after the Clinton-era failure to pass any major healthcare reforms.

40. See, e.g., James K. Sebenius, Sequencing To Build Coalitions: With Whom Should I Talk First?, in Wise CHOICES: DeCisions, GAMES, AND NEGOTIATIONS 324, 325-26 (R. Zeckhauser et al. eds., 1996). 
2008, decided to take their reforms directly to the people. ${ }^{41}$ Since Obama was elected on a platform of "change," strategists thought plans to change healthcare, in the face of identifying healthcare as a leading issue during the campaign ${ }^{42}$ would be welcomed at the grassroots level.

With less planning than dispute resolution professionals would have suggested, some early town-hall meetings were nothing more than relatively open sessions with hundreds-in a few cases, thousands-of participants. In many of the most controversial sessions with Senators Arlen Specter $^{43}$ and Claire McCaskill, ${ }^{44}$ the Senators appeared virtually alone, with a single microphone, and tried (in some cases, desperately) to control what turned out to be very unruly crowds. When Senator Specter was attacked at one town-hall meeting in Philadelphia-at which he appeared with Kathleen Sebelius, Secretary of Health and Human Services-neither of them seemed to be in control of the microphone or the meeting. There was little ground-rule setting, meeting management, conflict assessment, small-group discussion, or agenda following, which would have been present in more professionally managed large-group policy discussions. ${ }^{45}$

41. For a sketch of how political problem-solving can be dispersed to more "intermediate sites" of public participation, see generally Joshua Cohen \& Charles F. Sabel, Directly-Deliberative Polyarchy, 3 EUR. L.J. 313 (1997).

42. Some political commentators suggest that President Obama managed to capture this issue from Hillary Clinton during the Democratic presidential debates by offering "more moderate" change and pointing to her earlier failure. See Pildes, supra note 20 (arguing that one of the potential causes of the "extreme partisan polarization" in modern politics has been the "polarizing personalities of various recent political figures ... who forged political breakthroughs across party and ideological lines to enact major policy initiatives").

43. E.g., Panzramic, Crowd Explodes When Arlen Specter Urges That We Do This Fast, YOUTUBE (Aug. 2, 2009), http://www.youtube.com/watch?v=J-Bpshk5nX0; micahmj11x, The Crazies Come Out To Discuss HealthCare Reform, YOuTuBE (Aug. 2, 2009), http://www.youtube.com/watch?v= gS4MI8fuXzw\&feature=related.

44. Today Exclusive: McCaskill on Town Hall: "It Was Terrific" (NBC television broadcast Aug. 12, 2009), available at http://www.msnbc.msn.com/id/21134540/vp/32384500\#32384500; lanser06, Town Hall to Claire McCaskill: We Don't Trust You, YOUTUBE (Aug. 11, 2009), http://www.youtube.com/ watch?v=PDPpGJDelHI.

45. There are now several organizations, both for-profit and not-for-profit, that specifically manage meetings and arrange for such proceedings as town halls, dialogue groups, study circles, public conversations, and more formal governmental-policy and regulatory negotiations. For examples of two professional umbrella organizations, see INT'L ASS'N FOR PUB. PARTICIPATION, http://www.iap2.org (last visited Jan. 16, 2011), and NAT'L COAL. FOR DiALOGUE AND DELIBERATION, http:// www.ncdd.org (last visited Jan. 16, 2011). For an informative guide to resources helpful in building deliberation skills, see Resource Guide for Public Engagement, NAT'L COAL. FOR DIALOGUE AND DELIBERATION (Oct. 11, 2010), http://www.ncdd.org/files/NCDD2010_Resource_Guide.pdf. See also AMERICASPEAKS, http://www.americaspeaks.org (last visited Jan. 16, 2011); CONSENSUS BUILDING INST., http://www.cbuilding.org (last visited Jan. 16, 2011); EVERYDAY DEMOCRACY, http:// www.everyday-democracy.org (last visited Jan. 16, 2011); RESOLVE, http://www.resolv.org (last visited Mar. 18, 2011); NAT'L ISSUES FORUMS INST., http:/www.nifi.org (last visited Jan. 16, 2011); POLICY CONSENSUS INITIATIVE, http://www.policyconsensus.org (last visited Jan. 16, 2011); PUBLIC CONVERSATIONS PROJECT, supra note 12. 
As participants in the August 2009 town-hall meetings ${ }^{46}$ gathered in a variety of venues, both public media and private video (widely available on YouTube) portrayed sessions that were frequently interrupted by those opposing any major changes to private healthcare as currently delivered. One notorious sign ignorantly carried to one of the town-hall meetings proclaimed, "Keep the Guvmint (sic) out of my Medicare." ${ }^{47}$ Medicare is, of course, a federal government program, providing universal health insurance to those over sixtyfive.

High-level government officials, including senators, representatives, and cabinet officers, seemed quite shocked and blindsided by the disrupted meetings. To dispute resolution and deliberative democracy professionals, it seemed almost as if the professional politicians had a romanticized and unrealistic conception of town-hall meetings. It seemed as if they had their own conceptions of what it would be like to "go to the people" in a time far removed politically from the idealized (idyllically depicted) town-hall meetings of seventeenth- and eighteenth-century colonial New England (and continuing in a few smaller or more homogenous locations in the present era). ${ }^{48}$

In an important op-ed piece in the New York Times during the first set of town-hall meetings, political scientist and deliberative-polling advocate Professor James Fishkin argued research has demonstrated that the idealized town-hall format is not effective in larger groups (those with more than approximately 150 participants). ${ }^{49}$ But the town-hall meetings were advertised and managed as meetings for whole congressional districts of over 650,000 voters. And the "intimate" town halls were instead unrepresentative samples of interest groups and particularly committed (and angry) individuals who used the occasions to disrupt the meetings and garner media attention for signs and

46. Sponsored by representatives from both political parties, including Senators Specter (R-PA) and McCaskill (D-MO), Representatives Barney Frank (D-MA) and Adam Schiff (D-CA), and government officials including Secretary Sebelius, Vice President Biden, and even President Obama.

47. Eric Kleefeld, Tea Party Sign: Keep the Guvmint Out of My Medicare, Talking PoInTs Memo (Aug. 10, 2009), http://tpmdc.talkingpointsmemo.com/2009/08/tea-party-sign-keep-the-guvmint-out-ofmy-medicare.php.

48. At the Duke Law See You Out of Court: The Role of ADR in Healthcare symposium, commentator Ethan Katsh described still-successful town-hall meetings in his own New England town (Needham, Massachusetts, population 28,000) as very structured, with strong traditions of participation from generally polite people, respectful of the moderators' authority. Given his own experience as an expert on cyberspace communication, e.g., ETHAN KATSH \& JANET RIFKIN, ONLINE DISPUTE RESOLUTION: RESOLVING CONFLICTS IN CYBERSPACE (2001), he fully expected and hoped debate on the healthcare issues would offer the opportunity for mass deliberation on the Internet. Alas, conflict was, in fact, heightened in cyberspace commentary on healthcare. Ethan Katsh, Professor of Legal Studies \& Dir. of the Ctr. for Info. Tech. \& Dispute Resolution, Univ. of Mass. at Amherst, Commentary at the Duke Law and Contemporary Problems Symposium: See You Out of Court: The Role of ADR in Healthcare (Oct. 8, 2010). See also Michael ZuCKERMAN, PEACEABLE Kingdoms: NEW ENGLAND TOWNS IN THE EIGHTEENTH CENTURY 154-86 (1970).

49. James Fishkin, Town Halls by Invitation, N.Y. TIMES, Aug. 16, 2009, available at http:// www.nytimes.com/2009/08/16/opinion/16fishkin.html. 
outbursts denouncing "ObamaCare," "Socialism," and "the Nazi healthcare plan."

In an extreme example from a Dartmouth, Massachusetts town-hall meeting, when asked why he was supporting the Obama-supported "Nazi policy," Representative Barney Frank retorted, "On what planet do you spend most of your time? ... Trying to have a conversation with you would be like trying to argue with a dining room table. ${ }^{50}$ In another heated meeting in California on September 2, 2009, a self-identified small-business owner, Katherine Bragg, screamed at the top of her voice that this healthcare plan was being "rammed down our throats." ${ }^{\text {151 }}$ Bragg exclaimed that when she has tried to call her congressperson in the past, the staff has cut her off, claiming they "know best," and that the office responds to her opposition with emails stating, "Thank you for your support." ${ }^{52}$ Her rants at that meeting were met with cheers of approval, and a recording of the event received many viewings later on YouTube. Tempers and words flamed on "both" sides of the "yes or no" of healthcare reform-hardly the stuff of Habermasian deliberative discourse and "ideal speech conditions."

In another widely televised town-hall meeting, opponents of healthcare reform shouted (at close range) at Senator Arlen Specter, a beleaguered, longserving Republican who changed parties in order to hold his seat (unsuccessfully), after being one of the few politicians to cross party lines (on this as well as other issues, like abortion rights). After one calmer and relatively polite participant queried Senator Specter about how citizens were expected to read and understand a bill that even some congressional members had said was too long and complex to read all the way through, Senator Specter responded, "We have to make judgments very fast." This met with such uproarious explosions and paroxysms of shouts and applause that one (watching video of the meeting) cannot even hear his plaintive attempt to defend himself by assuring the gathered citizens: "I understand it before I vote."

Commentary following these less-than-successful attempts to engage the populace in a spirited, yet reasoned, debate about healthcare also followed polarized and partisan lines. On the conservative side, commentator Peggy Noonan suggested the Democrats were surprised to learn how the voters really felt, upset by the Obama Administration's assumption that because it had won on an "anti-Bush" campaign in 2008, the Administration was necessarily

50. Barney Frank Lashes Out at Protestor for Nazi Remark, U.S. News, Aug. 19, 2009, available at http://www.usnews.com/news/politics/articles/2009/08/19/barney-frank-lashes-out-at-protester-for-naziremark; see also PoliticsNewsPolitics, Barney Frank Confronts Woman at Town Hall Comparing Obama to Hitler, YOUTUBE (Aug. 18, 2009), http://www.youtube.com/watch?v=nYlZiWK2Iy8 (CNN Live News broadcast).

51. Speakmymind02, Woman Goes Nuclear at California Town Hall Meeting, YOUTUBE (Sept. 2, 2009), http://www.youtube.com/watch?v=aAm6Qck5v78\&NR=1.

52. $I d$.

53. Panzramic, supra note 43. 
guaranteed support of its health initiatives. ${ }^{54}$ Noonan accused a Democratic operative of calling the healthcare plan "Hillary's revenge." Claiming that the Democrats mistook Obama's victory for a "mandate without context," Noonan (as well as others) implied that after managing the economic crisis with expensive government bailout programs, the population was not ready to endorse another big government program. ${ }^{56}$ Noonan accused the "leftosphere and liberal commentariat" of failing to see the town-hall sentiments as "authentic," saying that people "show up only if they care." ${ }^{57}$ She also accused the Democrats of criticizing the town-hall meetings from two inconsistent sides, alleging that, on the one hand, the Democrats argued the town-hall participants were "ginned up," carrying swastikas and anti-government slogans. ${ }^{58}$ On the other hand, she claimed, the Democrats charged that the disrupters were "suspiciously well-dressed in jackets and ties from Brooks Brothers" and that "[t]hey must be Republican rent-a-mobs."

House Leaders Nancy Pelosi and Steny Hoyer were compelled to withdraw a statement they had made, in print and orally, that these town-hall protesters were "un-American." countered with allegations that they were suppressing First Amendmentprotected speech. Conservative commentator Ivan Kenneally wrote about Democrats who were prompted to "cancel appearances and limit their communications to press releases" and who "have attempted to squash public debate under the sheer weight of rhetorical condescension," increasingly aware of "unusually spirited opposition to Democrat proposals for sweeping reform." Kenneally accused the Administration of "attempt[ing] to fast-track an immensely complex piece of legislation, ensuring that a transparent national debate is impossible and that even our legislators remain ignorant of the details of the proposal." ${ }^{\prime 2}$

In a direct attempt to polarize democratic deliberation, commentators like Kenneally accused President Obama and his Administration of having "contempt for public debate[-]one of the hallmarks of [his] technocratic approach to politics," writing that "in place of healthy and democratic deference to public opinion, we get the assurance of expertise that comes with a

54. Peggy Noonan, "You Are Terrifying Us", WALl ST. J., Aug. 6, 2009, available at http:// online.wsj.com/article/SB10001424052970204908604574334623330098540.html.

55. Id.

56. Id. ("[T]hey thought that in the middle of a historic recession featuring horrific deficits, they could assume support for the invention of a huge new entitlement carrying huge new costs.").

57. $I d$.

58. Id. ("Nancy Pelosi . . . accused the people at the meetings of "carrying swastikas and symbols like that."').

59. Id. (attributing to Senator Barbara Boxer claims that these town-hall protesters "were 'well dressed,' that 'this is all organized,' 'all planned,' to 'hurt our president'”).

60. Ivan Kenneally, The Public Option, NAT'L REV. OnLINE, Aug. 12, 2009, available at http:// www.nationalreview.com/articles/print/228050.

61. Id.

62. Id. 
bevy of special-issue czars." ${ }^{63}$ Democratic deliberation, it is argued, is in opposition to expertise, specialization, and science. When they continue the polarizing refrains, Democrats are then, in turn, accused of "counter[ing] the healthcare critics" by organizing masses of union members to attend later town halls. ${ }^{64}$ Thus, far from the reasoned deliberation of many voices with different views, these town-hall meetings ${ }^{65}$ quickly deteriorated into very partisan shouting matches between administration officials seeking approval and support for healthcare reform and those opposed to virtually any government role in the healthcare system.

Despite conservative commentators' characterizing the meetings as "authentic" and "spontaneous," there is clear evidence that at least some of the opposition was, indeed, planned and orchestrated. In a memo called Rocking the Town Halls-Best Practices, Tea Party ${ }^{66}$ supporters were urged to follow the example set when Connecticut anti-reformists "pack[ed] the hall" and aggressively challenged Congressman Jim Himes during a May 2009 town hall. ${ }^{67}$ Based on their success at leaving Congressman Himes "staggered" with their "reality check from we-the-people," this right-wing group developed this bestpractices manifesto to "organize for success," and urged supporters to "use the Alinsky playbook of which the Left is so fond: freeze it, attack it, personalize it, and polarize it." ${ }^{68}$ The suggested best practices included moving oppositionists around the room to disrupt from within, meeting before town halls to plan strategies, holding press conferences before and after to "claim victory"; "rock[ing] the boat early in the Rep's presentation"; "yell[ing] out and challeng[ing] the Rep's statements early"; using protest signs outside the meeting; getting press coverage; developing hostile questions about the "Socialist" agenda and "be[ing] persistent" about asking them; getting the rest of the crowd to applaud your question; and making the questions long and complicated with statistics to put the Rep on the spot, "rattle him," and get him

63. Id.

64. Noonan, supra note 54.

65. And their media coverage, but that is a subject for another paper. See generally Symposium, International Media and Conflict Resolution, 93 MARQ. L. REV. 1 (2009), available at http:// epublications.marquette.edu/mulr/vol93/iss1.

66. The Tea Party movement originated from the slogan "Taxed Enough Already" (TEA), in reference to the Boston Tea Party rebellion against taxes on tea in the colonial era.

67. Bob MacGuffie, Rocking the Town Halls-Best Practices, in Memo Details Co-ordinated AntiHarassment Strategy 1, TALKING POINTS MEMO, http:/talkingpointsmemo.com/documents/2009/08/ memo-details-co-ordinated-anti-reform-harrassment-strategy.php?page $=1$ (last visited Jan. 17, 2011). See Dan Quinlan, Himes Faces Tough Crowd at Library, FAIRFIELDMinUTEMAN.COM, June 4, 2009, in id., at 4 (describing the disruption at the Himes town hall).

68. MacGuffie, Rocking the Town Halls, supra note 67, at 1 . The memo is referring to SAUL D. Alinksy, RUles fOR RADicAls: A PRACTICAl PRIMER FOR REALISTIC RADICALS (1971), a manifesto for progressive community organizing that, ironically, Tea Party and Right Principles organizers urged their supporters to use. 


\section{"off his agenda." ${ }^{69}$ Among a list of "focused questions for congressional representatives" are:}

1. You have broken the back of the American taxpayer. Just how much household debt do YOU think is enough?... $\ldots$

5. We all understand that National Health Care means rationing health care. What aspects of health care would you propose rationing? And to whom and what groups of people would you ration care? $?^{70}$

6. Why do you believe that government is more qualified to manage health care than private industry? Point to an area where government has successfully managed health care and exercised fiduciary responsibility. Medicare and Medicare [sic] have been financial failures. Point to a country where national health care has not been rationed?

7. YOU have voted for a socialist agenda. Please explain why you believe a socialist approach to governing, as opposed to a free market approach [,] is optimum. Do you believe that people would prefer their government to control their income, their health care, their retirement, their investments, their children's education, their choice of cars, what they eat and drink, etc.? ${ }^{71}$

Whether fully organized or not, one town-hall meeting after another was disrupted with leading or loaded questions like those above, $;^{72}$ hostile shouting, yelling, and screaming; uncontrolled outbursts and applause; and even, in a few cases, physical contretemps, leading to the removal of some protesters and even a few arrests. In very few televised portions of these meetings (and those viewable on YouTube) was an experienced moderator or facilitator present to manage and skillfully shape the conversation in a productive way. Those with President Obama were more orderly and controlled, in large measure because of pre-event and event security and ticketed, if not randomized, attendance.

At least one notable exception was Senator Claire McCaskill's solitary (standing at a podium on her own) but effective presence in presiding over her

69. MacGuffie, Rocking the Town Halls, supra note 67, at 1-2.

70. Sarah Palin managed to cleverly convert this issue into a claim that healthcare reform would result in "death panels" with the government deciding who would live or die. Those supporting healthcare reform explained that (1) there were no such things as "death panels" and (2) healthcare is currently "rationed" by private insurance companies, which could themselves be considered death panels.

71. MacGuffie, Focused Questions for Congressional Representatives, in Memo Details Coordinated Anti-Harassment Strategy, supra note 67, at 8.

72. Readers of this paper who are clinical professors, political consultants, journalists, and professional conflict resolution facilitators and moderators will know about the logic of question framing and the need for open-ended questions to really facilitate open discussion and information. See generally DAVID A. BINDER ET AL., LAWYERS AS COUNSElors: A CliENT-CENTERED APPROACH (2004) (focusing on client's perspective in lawyer-client communications); STEPHEN ELLMANN ET AL., LAWYERS AND CLIENTS: CRITICAL ISSUES IN INTERVIEWING AND COUNSELING (2009) (examining practical and theoretical challenges lawyers face with clients). For question protocols for facilitating meetings on controversial subjects, see generally PUBLIC CONVERSATIONS PROJECT, supra note 12. See also John P. ROBINSON \& ROBERT MEADOW, POLlS APART: A CALl FOR CONSISTENCY IN SURVEYS OF PUBLIC OPINION ON WORLD ISSUES (1982); ROGER SCHWARZ, THE SKILLED FACILITATOR: A COMPREHENSIVE RESOURCE FOR CONSUlTANTS, FACILITATORS, MANAGERS, TRAINERS, AND COACHES ( $2 \mathrm{~d}$ ed. 2002). 
own town-hall meeting. Given her midwestern, calm, experienced-electedofficial demeanor, ${ }^{73}$ she was actually able to keep some calm in her session. Utilizing a method commonly employed in more planned deliberative sessions, she asked participants to put their questions in a goldfish bowl, from which she would choose questions at random, thus delaying and distancing the personal invective and anger of the questioner. Coyly labeled "goldfish bowl democracy" by newscaster Keith Olbermann, ${ }^{74}$ McCaskill's town halls, though also disrupted, at least attempted to use some professional facilitator's tools.

In an interview on NBC's TODAY Show, following the disruption of her town-hall meeting, Senator McCaskill remained calm and empathetic to her attackers: "There were thousands of people there. I was proud of the people that showed up." "Even after having people scream "No" at her, Senator McCaskill said she didn't take it personally, explaining "these are people that are very distrustful of government." According to McCaskill, the people were misinformed. She appreciated that her state was "evenly divided" between Left and Right, so she was hoping to work toward a "compromise" in the middle for "stable insurance coverage." Commenting that she had brought her eighty-oneyear-old mother to the raucous session, Senator McCaskill said it was hard for her mother, who "isn't used to people who are that rude." She said that, generally, Missourians had "good manners." These people were not very effective, according to McCaskill: “Just because you're loud doesn't mean you're right." When queried as to whether the Administration was "push[ing] healthcare reform too fast," McCaskill acknowledged "pent-up frustration," but said the plan had to be "big and hard" to fix the problem. She was direct and responsive to questions from interlocutors at the town hall and in subsequent television interviews. Senator McCaskill is, perhaps, a more natural large-group facilitator.

In viewing and reading about the disruptions at the town-hall meetings, many factual and empirical questions remain. Though there was much anger and emotion expressed, it remains unclear how much disruption was individually motivated; many of those who shouted in anger had complaints about particular "adverse medical events" of family members, or about cost and financial issues regarding healthcare, while others clearly had much larger agendas than healthcare. Many of the organized protests pertained to specific

73. Of course, it is also possible that her gender had something to do with it; but Secretary Sebelius, also an experienced mid-western elected official, did not fare so well when she appeared at other town-hall meetings. For a discussion on the enormously complicated role of gender in dispute resolution roles, see generally Carrie Menkel-Meadow, Portia in a Different Voice: Speculations on a Woman's Lawyering Process, 1 BERKELEY WOMEN's L.J. 39 (1985); Andrea Kupfer Schneider, Catherine H. Tinsley, Sandra Cheldelin \& Emily T. Amanatullah, Likeability v. Competence: The Impossible Choice Faced by Female Politicians, Attenuated by Lawyers, 17 DUKE J. GENDER L. \& POL'Y 363 (2010).

74. Transcript of Countdown with Keith Olbermann, available at http://www.msnbc.msn.com/id/ 32386278/ns/msnbc_tv-countdown_with_keith_olbermann (MSNBC television broadcast Aug. 11, 2009).

75. Today Exclusive: McCaskill on Town Hall: “It Was Terrific”, supra note 44. 
objections to President Obama, to Democrats generally (unhappy "losers" from the last election sabotaging attempts at bipartisan conversation?), or to much bigger issues involving perceptions of "Big Government" or wasteful government spending. Still others expressed general frustration with government (both federal and state) that is large, expensive, and distant, all at a time of great economic uncertainty and two ongoing, divisive wars. It is very difficult to disentangle so many politically salient events and issues to study in any systematic way how the town hall-a, perhaps, over-romanticized form of deliberative democracy - could have been used in public consideration of a single, but very complex, issue like healthcare.

So what went "wrong," Assessing the failures of the healthcare town halls as an opportunity to scale up various forms of deliberative democracy raises the following questions about the theory and practice of large-scale policy deliberation and dispute resolution:

1. Was the "failure" of the healthcare town halls attributable to

a. the healthcare issue;

b. the political climate; or

c. naiveté about town-hall processes?

2. What forms of deliberative democracy could be used generally to promote informed public participation in policy making?

a. Are all issues treatable in the same way, or are some issues especially controversial, requiring different methods?

b. What is the relationship of collective or organized participation to individual participation in public-policy deliberation? (Are successful methods of ADR in smaller-scale disputes-such as active listening, empathy, interest-based negotiation, mediation, and facilitated group discussion-adaptable to highly organized and polarized group processes? ? $^{77}$ ) Are different kinds of processes necessary for different purposes (actual decision making and policy drafting versus educative or informational events)?

76. I write this as both a conflict resolution and deliberative democracy scholar and practitioner, and one who generally favored healthcare reform. Those who were trying to derail healthcare reform could claim that the town halls were quite successful - they helped remove a public option from the plan completely; drew media attention to popular opposition to healthcare reform; and very successfully polarized and simplified an otherwise extremely complex and nuanced issue.

77. The literature of multi-party and group dispute resolution is now replete with its own divergent theories about "groupthink," see generally IRVING JANIS, GROUPTHINK: PSYCHOLOGICAL STUDIES OF POLICY DECISIONS AND FIASCOES (1982) (describing the psychological processes at work within group decision making, particularly the human need for peer approval), and evolving extremism, see generally Cass R. Sunstein, Deliberative Trouble? Why Groups Go to Extremes, 110 YALE L.J. 71 (2000) (investigating the phenomenon of group polarization in public deliberation). 
c. What are the purposes of deliberative democracy? To educate (or persuade) the public on important issues? To measure existing public opinion (polling) or to change it (deliberative polling)? To develop policy alternatives or to discuss existing or proposed policies? To actually decide on what policies should be adopted or to simply discuss them ${ }^{78}$

3. How "democratic" is democratic deliberation really?

a. If scaled-up deliberation requires leadership and facilitation (through consensus-building or facilitated-policy dialogues), what is the theory behind expert facilitation in democratic models of equal participation?

b. If thoughtful deliberation requires adequate preparation and education (as in Fishkin's Deliberative Polling methods ${ }^{79}$ or structured-regulatory or legislative negotiation ${ }^{80}$ ), how democratic can the process be with teachers, leaders, guides, and dedicated time commitments ? $^{81}$

4. What constitutes deliberative discourse? Must it be "reasoned" or "reasonable"? What is the role of other forms of discourseemotions, instrumental trading, deep-value commitments, and differences - in efforts to develop an informed and respectful polity in democratic decision making?

In short, is it possible to scale up deliberative democracy to provide intelligent deliberative processes for consensual, political decision making?

78. In theory and in fact, all of these different purposes have been used in a wide variety of publicdeliberation events from consensus-building fora to public conversations, to study circles, to negotiated rulemaking. See, e.g., THE CONSENSUS BUILDING HANDBOOK 679-1087, supra note 11 (presenting cases and commentaries).

79. See generally FISHKIN, supra note 10.

80. E.g., Symposium on Collaborative Governance, 2009 J. DisP. RESOL. 269, 269-448 (2009).

81. The critiques of deliberative processes' time demands have been made for decades, most famously by Oscar Wilde: "The trouble with Socialism is that it takes up too many evenings," OsCAR WILDE: A LIFE IN QUOTES 238 (Barry Day ann. \& ed., 2000); and, more recently, by political theorist Iris Young and other feminist theorists, who note the class and gender assumptions regarding who is available to actively participate in time-consuming, democratic deliberative processes, see, e.g., IRIS MARION YOUNG, INCLUSION AND DEMOCRACY (2000) (noting those without childcare responsibilities and those who have flexible work schedules are usually the ones available). See generally IRIS MARION YOUNG, JUSTICE AND THE POLITICS OF DIFFERENCE (1990) (arguing that for many excluded or otherwise subordinated people, other forms of democracy-for example, public protests and narratives-might be more effective ways of expressing preferences); DEMOCRACY AND DifFERENCE: CONTESTING THE Boundaries OF THE Political (Seyla Benhabib ed., 1996) (reconsidering the foundations of democratic theory and practice in the light of the politics of difference). 


\section{CAN DELIBERATIVE DEMOCRACY Be SCALED UP? IS IT HEALTHCARE OR IS IT DEMOCRATIC PROCESS?}

Efforts to understand and then correct for these failed efforts at engaging the polity have been many since the town halls were abandoned, and a much more complex healthcare-reform bill was passed (absent the public-health program previously intended to compete with private insurance coverage).

Some claim the disruptions of the town-hall meetings were specific to the issue at hand: healthcare. Healthcare is simply "about life and death." ${ }^{\text {" }}$ It is not something that we are very rational about. Healthcare is something that everyone needs, that some have and some do not, and that virtually all are dissatisfied with. Healthcare is also a difficult issue because it separates different groups of haves and have-nots. In healthcare, all are stakeholders, but the stakeholders are very differentially endowed. Some have healthcare insurance and good services; some have only one of these things; some have neither. This is an issue that divides by class and geography. Some need healthcare perpetually (the chronically ill); some need it only briefly or temporarily (preventative-care patients, babies and children, or the occasionally ill). Some have single, or rare but catastrophic, healthcare needs (cancer victims, accident victims, or patients undergoing major operations); others are healthy (especially the young, who sometimes act as if they don't need healthcare at all, but whose parents often worry about and pay for their infrequent care and health insurance). This issue divides by age, geography, class, and luck; so there is some randomness and the potential for some empathy. But this also individualizes, rather than collectivizes, the issue. Those who vote are more likely to have healthcare than those who do not (another fact that divides by class and political participation-quite relevant in assessing the representativeness of these meetings).

Then there are the caregivers: dedicated but often unprofessional family members, most often women ${ }^{83}$ and the medical profession and its auxiliariesnurses, aides, institutional and home-based caregivers, and (increasingly now) immigrant workers. This issue also divides by class, geography, and ethnicity.

And then there are the divisions within the professional classes: malpractice lawyers, doctors, insurers, and victims of bad medical treatment or "adverse medical events" (the now commonly used euphemism), which may be suffered by individuals or large groups who can then profit from class actions and other aggregative litigation modes. ${ }^{84}$ This pits interest groups of various sorts against

82. Nancy Dubler, supra note 9 (pithily and accurately put).

83. See generally EMILY K. ABEL, WhO CARES FOR THE Elderly: PUblic POLICY AND THE EXPERIENCES OF ADULT DAUGHTERS (1991) (studying adult daughters' experiences as primary and private source of caregiving for elderly population).

84. In my own brief experience with healthcare reform in the Clinton Administration, Democrats in both the executive and legislative branches sought my advice on how to begin to structure alternative dispute resolution for a wide range of medical disputes. After watching many dedicated politicians, 
each other, many arguing that the high cost of malpractice insurance drives up the cost of medical care, and that "jackpot" jury verdicts line the pockets of a few "lucky" (from major injuries and accidents?) victims and an elite group of lawyers. ${ }^{8.5}$

Then there are the providers and suppliers of services: hospitals, pharmaceutical companies, medical-device companies, and medical-worker unions. These entities often compete for funds, sometimes in zero-sum distributive settings (in both for-profit and nonprofit organizational structures) and sometimes against common "foes" (food and drug regulations, health and safety standards, and the regulatory state, in general).

In short, healthcare- (and public-health-) policy issues have a large number of stakeholders, including everyone in the polity, but these people have very different "stakes" in the policy choices-both in terms of life and life-cycle experiences, as well as professional and financial issues.

In some theoretical models of disputing, this would be a good thing-many different interests could be used to trade and bargain across differently valued preferences $^{86}$ on different issues, and trades and bargains could be made. But as this issue developed in a partisan political environment and in a very public forum (in contrast to Hillary Clinton's initial desire to keep the healthcarereform process more private, which Elster suggested was a good thing in the American constitutional-formation process ${ }^{87}$ ), it became particularly difficult to make "trades" across class, interest, and role (professional and political) lines. This is slightly more possible in more confidential dispute resolution settings, commonly occurring in mass-tort, employment, and other forms of class-action litigation and settlements. ${ }^{88}$ Others argue that the finally enacted law is, in fact, the product of these "unprincipled" compromises, maintaining private insurance with public mandates of coverage, but that legislative negotiation was not the sort of "efficient," bargained-for trading that dispute resolution theorists had in mind. ${ }^{89}$

experts, and civil servants work very hard on possible legislation and regulation, these terms fell away as a large part of the Democratic Party's financial base (namely, the most successful of trial lawyers) effectively lobbied to remove these provisions.

85. Contra Tom BAKer, The MedicAl MAlPRACTICE MYTH (2005) (arguing that the real cause of high insurance premiums is not actually excessive malpractice litigation).

86. See supra Table 1 (column titled "Bargaining").

87. Elster, supra note 33, at 244.

88. See generally Carrie Menkel-Meadow, Ethics and the Settlements of Mass Torts: When the Rules Meet the Road, 80 CORNELL L. REV. 1159 (discussing ethical and procedural issues in mass torts and medical and health-related class-action settlements) (1995).

89. In close to thirty years of teaching negotiation (half of them in Washington, D.C.), I have always had to exclude legislative negotiation from the theories and practices that I teach. Legislative negotiation is neither distributive nor integrative. Even "mixed" legislative negotiation (including logrolling, "pork" bargaining, and other terms of art) does not conform to any existing model of negotiation. Thank you to my former student Donald Schriber (UCLA class of 1987) who recognized this in his first of many, many years on the Hill (and especially during the Clinton Administration's healthcare-reform process). 
So healthcare-with literally millions of stakeholders, both organized into interest groups and not organized at all-may, perhaps, be too vast, diffuse, and divisive a topic on which to model or practice our theories of deliberative democracy. Adding to the complexities of healthcare policy itself are unpredictable medical advances; new illnesses borne by pests, foods, and increased human interaction and transnational travel $;{ }^{90}$ staggering cost increases; and the divisiveness of the political process in the midst of an economic recession and two complex wars. The result is a political context that, perhaps, was (and is) too contentious for true, informed "deliberation" on this particularly difficult issue. Complicating this already complex situation is the possibility that healthcare became a "surrogate" for the general expression of opposition to the newly elected political regime. Instead of a truly issue-based discussion, the healthcare debate was the collective action of "sore losers" in the larger political environment. Structuring dialogue around a single issue, when other political issues may be inseparably intertwined, may prove particularly difficult.

Observing the healthcare town halls and the media reaction, one is struck by the daily enactment of one of our key dispute resolution concepts: "reactive devaluation." Whatever one "side" argued for, the other side immediately counter-"attacked" and rejected. In a complex environment like that of healthcare policy, issues are complex and multi-faceted and are not always binary-they can exist on a continuum. The pro and con debate and "agonistic" modes of discourse that were used in these meetings are particularly unhelpful in facilitating "reasoned" and "nuanced" discourse where policy choices are complex, intertwined, and interactive."

More sophisticated models of deliberation (including Public Conversations Project's protocols for facilitating difficult conversations ${ }^{94}$ ) seek to identify and utilize the sources of disagreement (not only from facts, but from different life experiences), the questions of uncertainty or incomplete information requiring further investigation, and the recognition of a gradation of views on certain subjects. For example, when I helped to co-facilitate deliberative fora for the

90. Lawrence O. Gostin, Global Health Law: International Law, Global INSTITUTIONS, AND WORLD HEALTH (Harvard Univ. Press, forthcoming 2012).

91. See generally Lee Ross, Reactive Devaluation in Negotiation and Conflict Resolution, in BARRIERS TO CONFLICT RESOLUTION, supra note 33, at 26 (exploring reactive devaluation theory and offering suggestions to overcome this artificial barrier to negotiation).

92. Deborah Tannen, The Argument Culture: Moving From Debate to Dialogue 34, 8-10 (1998).

93. Carrie Menkel-Meadow, The Trouble with the Adversary System in a Postmodern, Multicultural World, 38 WM. \& MARY L. REV. 5, 5 (1996) ("[P]olarized debate distorts the truth, leaves out important information, simplifies complexity, and obfuscates rather than clarifies."). See Lon L. Fuller, Mediation: Its Forms and Functions, 44 S. CAL. L. REV. 305, 312-14 (1971) (offering a classic description of disputes with "web-like" issue interaction).

94. Constructive Conversations about Challenging Times: A Guide to Community Dialogue, Version 6.0, Public CONVERSATIONS Project (Jan. 2011), http://www.publicconversations.org/docs/Comm GuideREVISEDJan2011.pdf. 
controversial Proposition 209 in California (dealing with affirmative action in education, employment, and government contracting), we were able to fractionate and compare views about affirmative action in three different spheres-education, employment, and public contracting. Within groups, opinions varied greatly on these three dimensions. Nonetheless, the political process ultimately turned these more nuanced discussions into yes or no votes on a single issue. ${ }^{95}$

In addition to reactive devaluation, polarization, and aggregation of issues, these town-hall meetings displayed many other forms of cognitive and social errors in deliberation, negotiation, and decision making ${ }^{96}$ (for example, anchoring, overconfidence, irrational escalation, status-quo bias, and endowment effects) with little to no evidence that those presiding over the meetings had any understanding of these concepts or how to manage them.

The town-hall meetings were also procedural disasters. The desire to "go straight to the people," with little thought about process design, made these meetings anarchistic and amorphous free-for-alls, with few formal ground rules and little facilitation or moderating. In some cases, a government officialwhether President Obama, a senator, or a cabinet official- "presided" over the meetings alone, making statements with "positions" and then eliciting random comments from lined-up questioners. There was little to no implementation of the now relatively well-developed formats of large policy debates-no evidence of consensus building, with ground rules, facilitation, brainstorming, recording, and small-group task forces ${ }^{97}$ no guided conversations with position-clarifying questions, as in the Public Conversations Project methods, ${ }^{98}$ no Scandinavian study circles; and no AmericaSpeaks-moderated fora ${ }^{99}$ with trained facilitators, smaller groups (at seated tables) feeding into larger plenary-group discussions, straw votes, and procedures for ordering and altering discussion topics. A variety of professionals, from AmericaSpeaks's Carolyn Lukensmeyer to Daniel Yankolovich, ${ }^{100}$ as well as many other public-policy facilitators, ${ }^{101}$ could have

95. Menkel-Meadow, supra note 93, at 34-35.

96. See Max H. Bazerman \& Margaret A. Neale, Negotiating Rationally 56 (1992) (discussing eliminating social and cognitive errors from "rational" negotiation); Daniel Kahneman \& Amos Tversky, Conflict Resolution: A Cognitive Perspective, in BARRIERS TO CONFLICT RESOLUTION, supra note 33, at 44, 46; JOHN A. BARGH \& EZEQUIEL MORSElla, The Unconscious Mind, 3 PersP. ON PSYCHOL. SCI. 1, 73, 76 (2008).

97. See generally THE CONSENSUS BUILDING HANDBOOK, supra note 11; LAWRENCE E. SUSSKIND \& JEFFREY L. CRUIKSHANK, BREAKING ROBERT'S RULES: THE NEW WAY TO RUN YOUR MEETING, BUILD CONSENSUS, AND GET RESUlts (2006) (providing practical guides on facilitating successful meetings).

98. For examples of dialogue guides, see Public Conversations ProjeCt, supra note 12.

99. AMERICASPEAKS, supra note 45.

100. See generally DANiEl YAnkelovich, The MAgic of Dialogue: Transforming CONFLICT INTO COOPERATION (1999) (exploring the concept of "transformative dialogue").

101. See Lawrence Susskind, How Should You Respond to the Noisy Health Reform Critics, THE CONSENSUS BUILDING APPROACH (Aug. 11, 2009, 12:15 PM), http://theconsensusbuildingapproach .blogspot.com. Other facilitators include Susan Poziba, Judy Innes, David Booher, Susan Carpenter, and Peter Adler. See also Symposium, Raising the Bar: What Deliberative Democracy Means for 
designed much more focused and facilitated processes to deal with these barriers to deliberative democracy. So what were the politicians who created and conducted these town-hall meetings thinking?

As noted above, an idealized version of American town-hall meetings may have prevented political strategists from understanding both the "science" and the "art" behind our conflict resolution field. Distinguished scholars, such as Thomas Schelling and Howard Raiffa, have demonstrated that numbers matter, and numbers matter a lot in decision making, negotiation, and dispute resolution. ${ }^{102}$ Town-hall-type meetings (like classrooms) have breaking points of about 150 , at which it is virtually impossible to carry an orderly conversation while maintaining full interaction among all participants. Thus, modern conflict resolution professionals know that plenary groups must be separated from task, committee, and caucus groups, feeding back into larger groups. Different sets of rules and procedures and different kinds of management, facilitation, and mediation are necessary for different group sizes. Small-group deliberation has its own set of issues and problems, so the two types of deliberative processes must be balanced and measured.

The different functions of deliberative bodies will also affect what processes can be used. Groups of people who vote and make decisions are different from groups of people who gather to learn from and inform their members. How one votes, what order parties speak in, and how discussion is monitored and "handed-off" to others are now all matters of study and best (and varied) practices in group deliberation. Whether group-deliberation events are designed to be informational or "sharing," rather than voting and decisional, is quite significant in terms of planning, structuring, and executing the actual practice of deliberative democracy. Whether groups should be fully transparent and public, or engaged in more confidential but (at least temporarily) secret conversations to reveal real needs and interests or to cut deals or compromises, is not so simple a question as it might appear in deliberative democracy practice, or even in theory. Thus, "realist proceduralists" who actually have experience in managing such complex issues and events are needed as empirical correctives to the overly romanticized and abstracted "procedural philosophy" of both Habermasian theorists and naïve political operatives.

Dispute Resolution, DisP. RESOL. MAG., Winter 2006, at 1 (featuring articles on discussions from the Workshop on Deliberative Democracy and Dispute Resolution, MIT, June 24-25, 2005). For more background, see PON, http://www.pon.harvard.edu (last visited Mar. 19, 2011) (Program on Negotiation at Harvard Law School); PUBLIC DisPUTES PROGRAM, http://web.mit.edu/publicdisputes (last visited Mar. 19, 2011) (MIT's project within PON at Harvard Law School dealing directly with public-policy disputes within countries).

102. See generally HowARD RAIFFA, THE ART AND SCIENCE OF NEgOtIATION (1982) (emphasizing the importance of recognizing mutual benefits in negotiation); HOWARD RAIFFA WITH JOHN RichaRdSON \& DAVID METCALFE, NEgOtIATION ANALYSIS: THE SCIENCE AND ART OF COLLABORATIVE DECISION MAKING (2002) (incorporating into negotiation analysis the concepts of individual-decision analysis, judgmental decision making, and game theory); THOMAS C. SCHELLING, THE STRATEGY OF CONFLICT (1960) (analyzing international conflict resolution in terms of game theory). 
Political strategists were blindsided by the organized and acrimonious presence of those known in the facilitation field as "hold-outs," "bad seeds," "troublemakers," "vetoes," "oppositionists," or (in simple nonjargon terms) "difficult people." There are ways and methods of dealing with such people and the situations they put us in during deliberation ${ }^{103}$ — short of silencing, removing, and arresting. Screening is one such method, but, like leadership and facilitation, it presents issues for democratic theory in deliberation. Trained mediators can help with "bad seeds" in smaller groups. Skilled public-policy facilitators use public shaming, exclusion, and disarming techniques. Whether such techniques work as well in public and televised meetings remains to be seen, tried, and evaluated.

In one sustained critique of the town halls, political scientist James Fishkin argued for his own "deliberative polling," which selects random members of a polity and then provides neutrally developed factual material to a representative subset. ${ }^{104}$ This material is then studied before the group appears at moderated and facilitated discussions of particular policy issues and choices. ${ }^{105}$ Fishkin has argued in a series of books and articles that such moderated and moderate discussion actually does change minds and opinions. ${ }^{106}$ Although his work remains controversial and not fully empirically validated, ${ }^{107}$ Fishkin presents a more modern deliberation model. Information and education first inform the deliberators, as opposed to tapping into strongly held (perhaps atavistic) attitudes and opinions-which are, perhaps, too vividly based on recent experiences or molded by familial, religious, or demographic characteristics and affiliations and, thus, may not shed specific light on particular issues.

Fishkin's models, like other deliberative democracy practices, are structured around trained leaders and facilitators. In contrast to the political theory and empirical studies of Jon Elster, or the feeling-centered and passion-focused political commentary of Senator McCaskill and Peggy Noonan, Fishkin's model still assumes a Habermasian world of reasoned persuasion and argument, even if aided by specific educational and procedural interventions.

Thus, even the new professional models of deliberative democracy leave us with some challenges in constructing effective deliberation fora on such volatile issues as healthcare. As a matter of democratic theory, the question remains whether the role of a professional facilitator or skilled moderator, which seems to be essential for orderly deliberative processes, must be more theorized and

103. See generally, e.g., Douglas StOne ET Al., Difficult CONVERSATIONS: How TO Discuss WHAT MATTERS MOST (2000) (providing a practical approach to facilitating challenging conversations).

104. See generally James S. Fishkin, THE VOICE OF THE PEOPLE: PuBliC OPINION AND DEMOCRACY (1995).

105. Id. at 161; FISHKIN, supra note 10 , at 80-85.

106. See generally, e.g., JAMES S. FISHKIN, DEMOCRACY AND DELIBERATION (1991).

107. See Lynn M. Sanders, Making Deliberation Cooler, 19 Good SoC'Y, no.1, 2010, at 41, 43 (stating that it "remains an open, empirical question whether" Fishkin's theories are "realistic"). 
justified within democratic theory. ${ }^{108}$ If participants are to be equal or, at least, equally heard under "ideal speech conditions," then how are we to justify a hierarchical structure of procedural expertise? Although such roles are justifiable and legitimate, as are other leadership roles in democracy (for example, presidents, senators, and judges), who chooses or votes for the leader or facilitator? Who can remove or reject such a leader-one only encountered in a meeting? By what process should ground rules be chosen? Democratically voted on? "Laid-down" by the expert facilitator? On what authority does the facilitator base her actions? And how much power does she have during a deliberative event to control process, choose speakers, and eject troublemakers? These are important issues and questions for theory and practice alike. ${ }^{109}$

The healthcare town halls so vividly highlighted an issue requiring our immediate theory-building and practical attention: the "passions" mode of deliberative discourse. ${ }^{110}$ How can, and how should, deliberative democracy deal with passions, emotions, and strongly held values, especially those which seem to be inconsistent with other people's equally strongly held values? Too much democratic and political theory has mistakenly focused exclusively on reason and principle. ${ }^{111}$ The economists (and some political scientists and policy and legal scholars) allow traded preferences and instrumental and (ultimately, they hope) efficient bargaining to come into the discourse. ${ }^{112}$ But not enough attention has been paid to managing "passions," emotions, values, or the "affective" dimensions in either dispute resolution or deliberative democracy. ${ }^{113}$ As a matter of practice, more conventional forms of dispute resolution at the

108. Carrie Menkel-Meadow, The Lawyers' Role in Deliberative Democracy, 5 NEV. L.J. 347, 36263 (2004-2005). See also Joshua Cohen, Procedure and Substance in Deliberative Democracy, in DELIBERATIVE DEMOCRACY: ESSAYS ON REASON AND POLITICS 407, at 422 (James Bohman \& William Rehg eds., 1997); Sanders, supra note 107, at 42.

109. As one wise sage once said (Yogi Berra?), in theory, theory works; in practice, it doesn't. Or, as Donald Schön suggests, a theory is only as useful as a "theory in use"-a theory that works (to explain, to guide). DonAlD A. SCHÖN, ThE ReFleCtiVE PRACTITIONER 10-11 (1983). See generally Carrie Menkel-Meadow, The Lawyer as Consensus Builder: Ethics for a New Practice, 70 TENN. L. REV. 63 (2002).

110. See supra Table 1 (column titled "Passions").

111. For examples of theorists (and feminists of my generation) who counterweight emotions or other processes to "pure reason," see generally VIRGINIA HELD, THE ETHICS OF CARING: PERSONAL, Political, And Global (2006); ARlie Russell Hochschild, The Managed Heart (1983); CAROl Gilligan, In A DifFERENT VOICE (1982); Nel NODDINGS, CARING: A FEMININE Approach to ETHics AND Moral EduCATION (2003); The PAssions of LAW (Susan A. Bandes ed., 2001).

112. See supra Table 1 (column titled "Bargaining").

113. For examples of efforts to deal with these issues in dispute resolution practice, see generally E. FRANKLIN DUKES ET AL., REACHING FOR HIGHER GROUND IN CONFLICT RESOLUTION: TOOLS FOR POWERFUl GROUPS AND COMMUNITIES (2000); JOHN FORESTER, DEALING WITH DIFFERENCES:

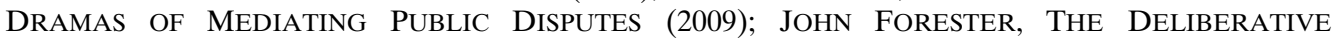
Practitioner: Encouraging PARticipatory Planning Processes (1999); LAWrence

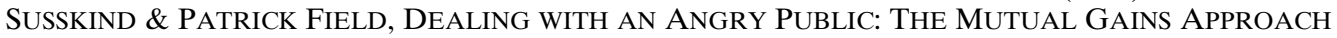
TO RESOLVING DISPUTES (1996). 
individual level, like mediation, clearly allow emotions in the room. ${ }^{114}$ (What mediator would work without a box of tissues?) As our polity is increasingly polarized and exaggerated by extremists and media, there appears to be less and less reasoned deliberation in political discourse, as well as in voting patterns (which increasingly swing alternatively between elections and appear to be less stable). Political realists watching these events must wonder: what planet are the deliberative democracy theorists living on $?^{115}$

Deliberative democracy processes in very large groups, with very complex and divisive issues, cannot be casually assigned to such unstructured events as town-hall meetings. What was the purpose of those meetings? To learn what the public in its myriad views actually thought? To get new ideas from lay people about very complex financing, insurance, medical, and economic issues? Or to hope to round up popular support to discipline the recalcitrant Republicans? If this last possibility was the objective, on what planet were the Democratic strategists living on? Having appropriated mass-protest, demonstration, and disruptive tactics from one of the leading organizers of the Left in the 1960s, ${ }^{116}$ the "other side" of the healthcare-reform issues then adapted these political strategies to the new Republican or Tea-Party populism, effectively subverting what town-hall planners had hoped would be more civil discourse. But did Democrats really hope and expect that civil discourse and one-way lectures or "information dumps" were going to lead to more approval of their alreadyframed plans? Was the "hijacking" of the town halls really a subversion of truly deliberative processes, or were the disruptive tactics merely an "interruption" of a similarly nondeliberative one-way process?

I am a registered Democrat (by party affiliation), and I am a democrat (in political and philosophical terms), as well as a dispute resolution professional who still believes we can facilitate deliberation of people's different views and come to some understandings, even those with which we really disagree. When the stars align and the facilitators are really well qualified, we actually can make

114. Many criticize mediators for not dealing with emotions "appropriately," however, often urging parties to move on to the future, without properly dealing with past feelings. See Trina Grillo, The Mediation Alternative: Process Dangers for Women, 100 YALE L.J. 1545, 1572-81 (1991) (discussing the role of emotion and anger in mediation); Carrie Menkel-Meadow, What Trina Taught Me: Reflections on Mediation, Inequality, Teaching and Life, 81 MINN. L. REV. 1413, 1420 (1997) ("[T] he reality [of mediation] is a tightly controlled "permitted' discourse which constantly polices by reminding that 'anger is counterproductive' to good solutions and long-term healthy relationships."). See generally Carrie Menkel-Meadow, Remembrance of Things Past? The Relationship of Past to Future in Pursuing Justice in Mediation, 5 CARDOZO J. CONFLICT RESOL. 97 (2004).

115. So some of those committed to truly deliberative processes, e.g., LAWRENCE SUSSKIND \& JEFFREY CRUIKSHANK, BREAKING THE IMPASSE: CONSENSUAL APPROACHES TO RESOLVING PUBLIC DISPUTES (1989), have now suggested a more radical overhaul of our entire political process. See SOl ERDMAN \& LAWRENCE SUSSKIND, THE CURE FOR OUR BROKEN POLITICAL PROCESS: HOW We CAN GET OUR POLITICIANS TO RESOlVE THE ISSUES TEARING OUR COUNTRY APART 27 (2008) (suggesting restructuring elections be based on votes for "best solutions" to particular problems and applied not only to congressional elections but to committee-selection processes in Congress and other deliberative bodies).

116. See ALINSKY, supra note 68 (providing strategies for progressive movements). 
policy choices and decisions across party lines. But it is also clear that we need to be realists and, as any good facilitator knows, we must have a strategy in place to deal with those "difficult people" outliers, holdouts, and obstructionists. One way to do that is to take strongly held views and emotions seriously and begin to realize that we need all forms of discourse: principled reason, instrumental bargaining, and, in addition, feeling-based claimsinvolving the recognition, if not acceptance, of the passions and emotions of others.

We need to develop a theory of how to weave these three levels of discourse into large-scale and complex political issues. Small-group mediation, facilitation, and overly structured deliberative polling cannot simply be scaled up by the numbers. The numbers and structures matter. Howard Raiffa ${ }^{117}$ spent much of the last part of his career trying to understand at what breaking point the number of people present begins to affect the dynamics of decision making and facilitation. He studied how dangerous assumptions of prisoner's dilemma games of "gotcha," "defection," and revenge-seeking (our current mode of political action) could be mitigated by other behavioral strategies. ${ }^{118}$ I have spent a large part of my career (as both a dispute resolution professional and feminist theorist) trying to recognize the importance of multiple value systems in any dispute resolution enterprise. If we are to scale up deliberative democracy, we must develop more sophisticated theories and practices with respect to both numbers and feelings.

Perhaps the biggest challenge in all of this is to determine the appropriate goals of such sessions. One might use one strategy to simply inform people about what the government or some other subgroup or party is proposing and to seek their reactions and opinions. This can more effectively be done through other means-like representative political polling. ${ }^{119}$ If policy makers are actually interested in generating new solutions or ideas, then other forms of participatory democracy may be better suited to the function than a large and unruly meeting. This is where questions about substantive expertise and more popular or more democratic ideas can get messy. Some policy questionstaxation, financing social-welfare programs, the stimulus package, climate change, and ideas about how to save or restart the economy-are very complex and require scientific, as well as value-based, choices and decisions. This is

117. One of my intellectual mentors. See RAIFFA, supra note 102.

118. Such as the prisoner's dilemma computer game's winning strategy of "tit for tat": be trusting, reciprocal, defect only when defected against, and be forgiving to encourage learning. See ROBERT AXELROD, THE EVOLUTION OF COOPERATION 27-54 (1984).

119. Not all polling is candidate or election based. Modern pollsters (like my husband!) are often the guardians of democratic information on issues and policy matters. National polling firms like Gallup, NYTimes/CBS, Pew, and the Kaiser Family Foundation have multiple methods for finding out what people think (and want) on many different policy issues. These scientific and random-selection polls can be used by legislators, policy groups, and, yes, interest groups; but the scientific ones (not "push polling") actually give much more accurate and representative information about what people in any level of polity actually think than large, badly managed, "voluntary" group meetings like the town halls. 
where the free-for-all of more open and fully participatory meetings differs significantly from Fishkin's deliberative polling and Scandinavia's study circles, where everyone is given information in advance of talking and deliberating. These events are more managed and are still based on notions of rational argument and discussion.

Any major public decision on a major policy issue like healthcare, must also address political theory issues of whether direct or representative democracy will be the better approach. Many issues in American political history were, in fact, "decided" by more popular forms of direct action, if not direct voting - the end of the war in Vietnam, the Civil Rights Movement, and the Women's Movement. All these began in well-organized and spontaneous mass actions fueling more direct participation in the polity. Some of these issues and their events had clear leaders (Martin Luther King Jr., Betty Friedan, and Gloria Steinem); others did not. But these important issues engaged more than merely rational thinking, argument, and reasoned persuasion. Martin Luther King Jr. used biblical, religious, and ethical appeals; the Women's Movement used anger and changed social mores (on such issues as childrearing, divorce, reproduction, and women's employment); the antiwar movement even used some physical violence (draft-card burning, protests before draft boards ${ }^{120}$ ). So we know that engaged and participatory politics uses more than argument, reason, and voting.

"Realistic philosophers" like Sen have urged us to use more broadly discovered and more diverse narratives, stories, histories, and data to assess different ways of hearing about and then evaluating particular policy choices. Skilled public-policy facilitators like Larry Susskind have successfully mediated important policy choices in budget allocations, environmental siting, naturalresource utilization (including large-scale global agreements and treaties ${ }^{121}$ ), and even highly conflictual value disputes like "faith-based" social and public assistance, animal rights, and abortion-clinic-access rights. ${ }^{122}$ Listening to stories, brainstorming alternatives, and finding out what people really value engages all three "senses" involved: reasoned argument (the mind), bargaining and trading (the gut-what we can "stomach" to get what we want from and with others), and our emotional and value-based commitments (the heart). To use all these discourses productively in political debate on highly contested issues requires more structure, more variation in ways of managing political communication ("process pluralism"), and more trust between and among the parties than we currently seem able to muster.

120. Including the bloody activity of the Catonsville Nine and the brothers Berrigan (priests) in protesting military action and mandatory military service in an "unjust war."

121. See generally INTERNATIONAL ENVIRONMENTAL TREATY MAKING (Lawrence E. Susskind et al. eds., 1992); ENGAGING COUNTRIES AND STRENGTHENING COMPLIANCE WITH INTERNATIONAL ENVIRONMENTAL ACCORDS (Edith Brown Weiss \& Harold K. Jacobson eds., 2000).

122. For case studies on some successful mediations, see generally THE CONSENSUS BUILDING HANDBOOK, supra note 11. 
So pick your next politically divisive issue in healthcare (abortion, stem-cell research, end-of-life decision making) or politics (the conduct-of-war policy, prison policy, economic policy), and imagine what kind of structure for conversation we would need in order to really hear all sides and to truly deliberate and learn from others who feel and think and reason differently than we do. ${ }^{123}$ And then think about what facts are needed to understand these issues (for example, what science, medicine, economics, behavioral and cognitive psychology, and sociology must be introduced and understood by the deliberators). Then think about the ways in which what we think and feel can affect (and distort) how we process information, form opinions, and come to our ultimate conclusions. And, finally, even if we could design a truly deliberative conversation on these and other complex issues, consider how our system eventually turns most of these questions into simplistic on or off, yes or no decisions in a two-party system requiring either majority or super-majority votes. ${ }^{124}$ Are deliberative democracy, wise decision making, and good policy choices even possible in such a polarized and binary world? Our healthcare debates don't provide much optimism. ${ }^{125}$ Rather, the recent town-hall meetings make clear that our efforts to scale up deliberative democracy in dispute resolution remain a work in progress. ${ }^{126}$

123. As I write this, President Hamid Karzai and the Taliban are in negotiations about ending the war in Afghanistan. Karen DeYoung et al., Taliban in High-Level Talks with Karzai Government, Sources Say, WASH. POST, Oct. 6, 2010, available at http://www.washingtonpost.com/wp-dyn/content/ article/2010/10/05/AR2010100506249.html.

124. Many political matters, like school financing, taxation, and constitutional amendments, require more than a simple majority, either of a legislature or in a referendum process.

125. Especially now, as the recently passed Patient Protection and Affordable Care Act is being attacked in the courts as an unconstitutional mandate, further polarizing the discussion. Two lower courts have held the Act to be unconstitutional. See Florida v. U.S. Dep't of Health and Human Servs., 2010 WL 2000518 (N.D. Fla. Apr. 8, 2010); Virginia ex rel. Cuccinelli v. Sebelius, 702 F. Supp. 2d 598 (E.D. Va. 2010). And several courts have upheld the Act, against constitutional attacks. See Thomas More Law Ctr. v. Obama, 720 F. Supp. 2d 882 (E.D. Mich. 2010); Mead v. Holder, 2011 WL 611139 (D.D.C. Feb. 22, 2011). See generally Randy Barnett, Commandeering the People: Why the Individual Health Insurance Mandate is Unconstitutional, 5 N.Y.U. J.L. \& LIBERTY 581 (2011) (concluding that the Act's individual mandate-requiring all persons to purchase private health insurance-is unconstitutional under existing Supreme Court doctrine on the Commerce and Necessary and Proper Clauses and the tax power).

126. For more views on the current role of deliberative democracy in dispute resolution, see generally Hiro N. Aragaki, Deliberative Democracy as Dispute Resolution? Conflict, Interests and Reasons, 24 Ohio St. J. ON DisP. Resol. 407 (2009); Amy J. Cohen, Dispute Systems Design, Neoliberalism, and the Problem of Scale, 14 HARV. NeGOT. L. ReV. 51 (2009); Sandy Heirbacher, Upgrading the Way We Do Politics, Yes!, Aug. 21, 2009, available at http://www.yesmagazine.org/ democracy/upgrading-the-way-we-do-politics. 